\title{
Pendampingan Lansia Dengan Dimensia Di Kelurahan Pocanan RW II Kota Kediri
}

\author{
Yuly Peristiowati ${ }^{1 *}$, Muhamad As'ad Efendy ${ }^{2}$, Nurwijayanti ${ }^{3}$ \\ ${ }^{1,2,3}$ Institut Ilmu Kesehatan STRADA Indonesia \\ yulystikes@gmail.com
}

\begin{abstract}
ABSTRAK
Lanjut usia (Lansia) adalah kelompok penduduk yang berumur 60 tahun atau lebih saat ini di seluruh dunia di perkirakan mencapai 500 juta dan diperkirakan pada tahun 2025 akan mencapai 1,2 miliyar. Kepikunan (demensia) merupakan fenomena yang sering terjadi pada lansia, yang ditandai dengan gejala-gejala yang menunjukkan terganggunya fungsifungsi memori (daya ingat), berbahasa, berpikir dan berperilaku. Prevalensi demensia diperkirakan $15 \%$ dari populasi usia lanjut Dimensia pada lansia sangatlah berpengaruh pada kehidupan sehari hari dan keluarga. Dimensia jika tidak di cegah sejak dini dapat membuat lansia menjalani hidup yang tidak optimal dan produktifitasnya menurun Kegiatan pengabdian ini diawali kegiatan survey di Kelurahan Pocanan Kota Kediri untuk mengidentifikasi lansia yang mengalami dimensia. Selanjutnya dilakukan kegiatan pendampingan pada lansia yang mengalami dimensia. Dari hasil survey awal dengan menggunakan metode Mini Mental State Examination (MMSE) teridentifikasi 11 lansia tidak mengalami gangguan kognitif, 5 lansia mengalami gangguan kognitif sedang dan 8 lansia mengalami gangguan kognitif berat. Selanjutnya di lakukan pendampingan pada lansia yang mengalami gangguan kognitif sedang dan berat dengan di lakukan beberapa intervensi diantaranya melatih ketajaman otak dengan permainan yang bisa mengasah otak, seperti puzzle, catur, senam otak dan ceki card. Hasil yang didapatkan dari kegiatan pengabmas ini lansia mempunyai kegiataan yang mendukung penurunan kognitif sehingga dapat menurunkan kondisi dimensia. Setelah pendampingan selama 2 minggu ini diharapkan lansia dapat melakukan dengan mandiri kegiatan-kegiatan untuk mengurangi dimensia yang dialaminya.
\end{abstract}

Kata Kunci: Lansia, Dimensia, Mini Mental State Examination

Received: October, 17, 2019

Revised: December 12, 2019

Accepted: February 11, 2020

\section{(c) (1) (2)}

This is an open-acces article distributed under the terms of the Creative Commons Attribution-ShareAlike 4.0 International License

\section{PENDAHULUAN}

Latar belakang munculnya kegiatan pengabdian masyarakat ini berawal dari survey di kelurahan Pocanan Kota Kediri, dengan mengidentifiksi adanya permasalahan tentang lansia yang mengalami dimensia. Data dari studi pendahuluan di dapatkan banyak lansia yang sering lupa pada aktivitas sehari hari. Sebagai contohnya "R" ketika di wawancarai menyampaikan sering merasa lupa kalau sudah makan,lupa sudah mandi apa belum, lupa sudah sholat apa belum, selain itu juga sering lupa sama nama anak-anak dan cucunya. 


\section{Journal of Community Engagement in Health}

http://jceh.org

ISSN: 2620-3758 (print); 2620-3766 (online)

https://doi.org/10.30994/jceh.v3i1.25

Vol.3 No.1. March 2020. Page.11-20

Selanjutnya di lakukan pemeriksaan dengan menggunakan Mini Mental state Examination (MMSE). Dari hasil pemeriksaan dengan MMSE didapatkan data 11 lansia $(45,8 \%)$ tidak ada gangguan kognitif, 5 lansia( 20,8\%) mengalami gangguan kognitif sedang, 8 lansia $(33,4 \%)$ mengalami gangguan kognitif berat. Sedangkan dari hasil analisa cross tabulasi antara gangguan kognitif dengan usia lansia didapatkan lansia yang mengalami gangguan kognitif berat tergolong old lansia yaitu usia 75-90 tahun.

Tabel 1. Identifikasi gangguan kognitif pada lansia dengan menggunakan metode MMSE di kelurahan Pocanan Kota Kediri April 2017

\begin{tabular}{|l|l|l|}
\hline Kategori & Frekuensi & Prosentasi(\%) \\
\hline Tidak ada Gangguan kongnitif & 11 orang & 45,8 \\
\hline Gangguan Kongnitif sedang & 5 orang & 20,8 \\
\hline Gangguan Kongnitif berat & 8 orang & 33,4 \\
\hline \multicolumn{1}{|c|}{ Total : } & 24 lansia & 100 \\
\hline
\end{tabular}

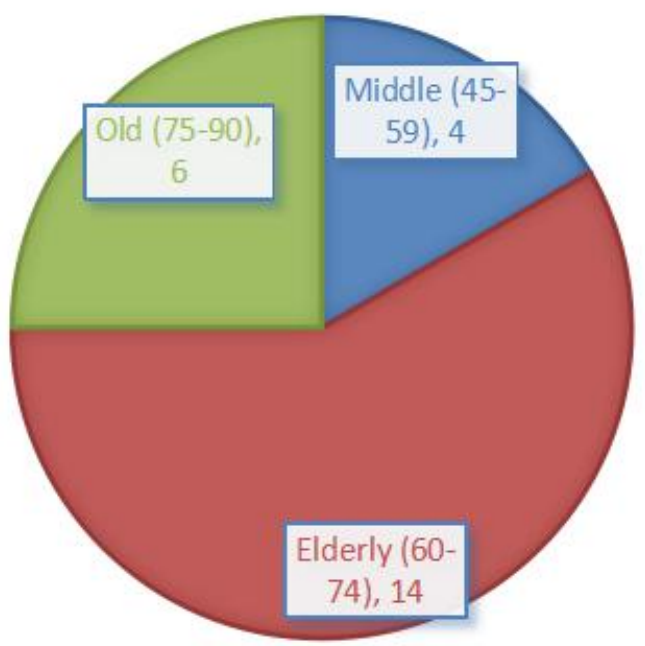

Diagram 1 . Klasifikasi Umur lansia di kelurahan pocanan Rw 02 kota Kediri April 2017

Tabel 2 :Tabulasi silang Klasifikasi gangguan kognitif dengan Usia Lansia

\begin{tabular}{|l|c|c|c|c|c|}
\hline Kategori & Middle age & Elderly & Old & Jumlah & Prosentasi (\%) \\
\hline Tidak ada gangguan kongnitif & 4 & 7 & 0 & 11 & 45,8 \\
\hline Gangguan kongnitif sedang & 0 & 4 & 1 & 5 & 20,8 \\
\hline Gangguan kongnitif berat & 0 & 3 & 5 & 8 & 33,4 \\
\hline
\end{tabular}

Masalah yang dihadapi pemerintah kota Kediri khususnya lansia adalah jumlah lansia di kota Kediri semakin meningkat dari tahun ketahun dan akibat dimensia banyak lansia yang tidak bisa mandiri dalam pemenuhan kebutuhan sehari-harinya. Usaha yang pernah dilakukan pemerintah kota Kediri dalam penanganan masalah lansia adalah pengaktifan posyandu lansia di tiap tiap desa, pembentukan kader posyandu, dan pemeriksaan kesehatan secara berkala terhadap lansia. Namun secara khusus untuk penanganan terkait dimensia belum dilakukan secara intensif.

Sejalan dengan penemuan masalah tersebut maka perlu dilakukan kegiatan pengabdian masyarakat untuk memberikan pemecahkan masalah tentang penanganan 
lansia yang mengalami dimensia melalui pendampingan untuk meningkatkan kognitif dan mengurangi dimensia pada Lansia. Program pendampingan yang di rencanakan akan dilakukan secara bertahap mulai dari identifikasi dimensia, implementasi dan evaluasi.

\section{METODE}

Metode Pendekatan program yang di lakukan yaitu :

a. Implementasi identifikasi terjadinya dimensia pada lansia di kelurahan Pocanan Kota Kediri

b. Implementasi pendampingan pencegahan dimensia pada lansia yang belum mengalami dimensia

c. Implementasi pendampingan penanganan dimensia pada lansia yang sudah mengalami dimensia

Prosedur Realisasi Program

Pada tahap persiapan pendampingan lansia adalah penentuan lokasi, pengenalan kegiatan pada lansia, identifikasi dimensia pada lansia menggunakan Mini Mental State Examination (MMSE).

Pada tahap pelaksanaan kegiatan pendampingan di bagi menjadi dua kelompok yaitu lansia yang belum mengalami dimensia sebanyak 11 orang dan lansia yang sudah mengalami dimensia sebanyak 13 orang. Selanjutnya di tentukan waktu pendampingan pada masing-masing kelompok lansia. Untuk kelompok lansia yang belum mengalami dimensia di berikan pendampingan selama 1 minggu sedangkan kelompok lansia yang sudah mengalami dimensia dilakukan pendampingan selama 2 minggu. Setelah waktu pendampingan disepakati dengan lansia pada masing-masing kelompok, maka akan dilakukan home visite pada masing-masing lansia, atau pendampingan pada saat lansia melakukan kegiatan posyandu lansia.

Pendampingan pada lansia yang belum mengalami dimensia dengan cara melatih ketajaman otak dengan permainan yang bisa mengasah otak, seperti mendengarkan musik, membaca, berhitung dan senam otak. Sedangkan pada lansia yang sudah mengalami dimensia di lakukan pendampingan untuk kegiatan belajar berhitung dan senam otak.

Implementasi identifikasi dimensia pada lansia di kelurahan pocanan kota Kediri di lakukan pada hari Rabu tanggal 15 april 2017 di posyandu lansia RW 02. Posyandu di hadiri oleh 24 lansia. Selanjutnya masing-masing lansia dilakukan pemeriksaan rutin seperti tensi, timbang berat badan dan dilakukan pengisian MMSE oleh mahasiswa STIKes Surya Mitra Husada Kediri bersama dosen pembimbing.

Kegiatan yang dilakukan :

1. Implementasi pendampingan pencegahan dimensia pada lansia yang belum mengalami dimensia

Implementasi ini di lakukan dengan cara melakukan kunjungan pada lansia yang belum mengalami dimensia. Dilakukan 3 kali dalam satu minggu selama 1 minggu bagi lansia yang belum mengalami dimensia sedangkan 2 minggu bagi lansia yang sudah mengalami dimensia.

Implementasi yang dilakukan pada lansia di kelurahan pocanan RW 02 kota kediri adalah : 
1. Beri kesempatan pada lansia untuk mengenal barang milik pribadinya misalnya tempat tidur,lemari, pakaian dan lain lain.

2. Beri kesempatan pada pasien untuk mengenal dengan waktu menggunakan jam besar, kalender yang mempunyai lembar perhari,dengan tulisan yang besar.

3. Beri kesempatan pada pasien untuk menyebutkan namanya dengan anggota keluarganya yang terdekat.

4. Berikan pujian jika pasien dapat menjawab dengan benar.

5. Berikan kesempatan kepada pasien untuk mengenal dimana dia berada.

6. Observasi kemampuan pasien untuk melakukan aktifitas sehari hari.

7. Beri kesempatan kepada pasien untuk memilih aktifitas yang dapat di lakukannya.

8. Bantu pasien untuk melakukan kegiatan yang telah di pilihnya

9. Tanyakan perasaan jika pasien mampu melakukan kegiatannya

10. Bersama pasien membuat jadwal kegiatan sehari hari.

Tindakan yang di lakukan pada keluarga bertujuan agar keluarga mampu mengorientasi pasien terhadap waktu, orang dan tempat, serta dapat menyediakan sarana yang di butuhkan pasien untuk melakukan aktifitas sehari hari tindakan yang di lakukan oleh keluarga adalah:

1. Diskusikan dengan keluarga cara cara mengorientasikan waktu, orang dan tempat pada pasien.

2. Anjurkan keluarga untuk menyediakan jam besar, kalender dengan tulisan besar

3. Diskusikan dengan keluarga kemampuan yang pernah di miliki pasien saat ini

4. Anjurkan kepada keluarga untuk memberikan pujian terhadap kemampuan yang masih di miliki oleh pasien

5. Anjurkan kepada pasien untuk memberikan pujian jika pasien selesai melukan kegiatan yang sudah di buat.

\section{Implementasi pendampingan penanganan dimensia pada lansia yang sudah mengalami dimensia}

Pada lansia yang sudah mengalami dimensia dilakukan pendampingan lebih intensif terutama melibatkan keluarga lansia dalam memberikan intervensi. Intervensi yang dilakukan pada dasarnya sama dengan lansia yang belum mengalami dimensia namun lebih intensif. Metode yang digunakan diantaranya senam otak. Yaitu Senam otak berfokus pada kebugaran kognitif dan psikis melalui rangkaian gerakan dan latihan. Pendampingan pada lansia juga dilakukan senan orak. Gerakan pada senam otak adalah :

a. Gerakan Silang (Cross Crawl)

b. Gerakan gajah (The Elephant)

c. Gerakan putaran leher

d. Gerakan Burung Hantu (The Owl)

e. Gerakan lambaian tangan

f. Gerakan pernafasan perut

g. Gerakan menguap berenergi

Pada tahap akhir kegiatan pendampingan akan di lakukan evaluasi. Evaluasi bertujuan untuk melihat perkembangan dan kemajuan program yang di laksanakan , sekaligus untuk mengetahui kendala dan penyelesaian sehingga program ini dapat benar-benar efektif dan maksimal serta berguna bagi masyarakat. Kemudian akan di ketahui pula adanya penurunan kejadian dimensia pada lansia setelah di lakukan program pendampingan. Evaluasi menggunakan alat ukur MMSE dan wawancara 


\section{Journal of Community Engagement in Health}

http://jceh.org

ISSN: 2620-3758 (print); 2620-3766 (online)

https://doi.org/10.30994/jceh.v3i1.25

Vol.3 No.1. March 2020. Page.11-20

secara langsung. Dari lansia yang sebelumnya mengalami gangguan kognitif berat meningkat menjadi gangguan kognitif sedang bahkan tidak ada gangguan kognitif.

3. Dokumentasi Kegiatan yang di lakukan adalah sebagai berikut :

Kegiatan mengukuran MMSE
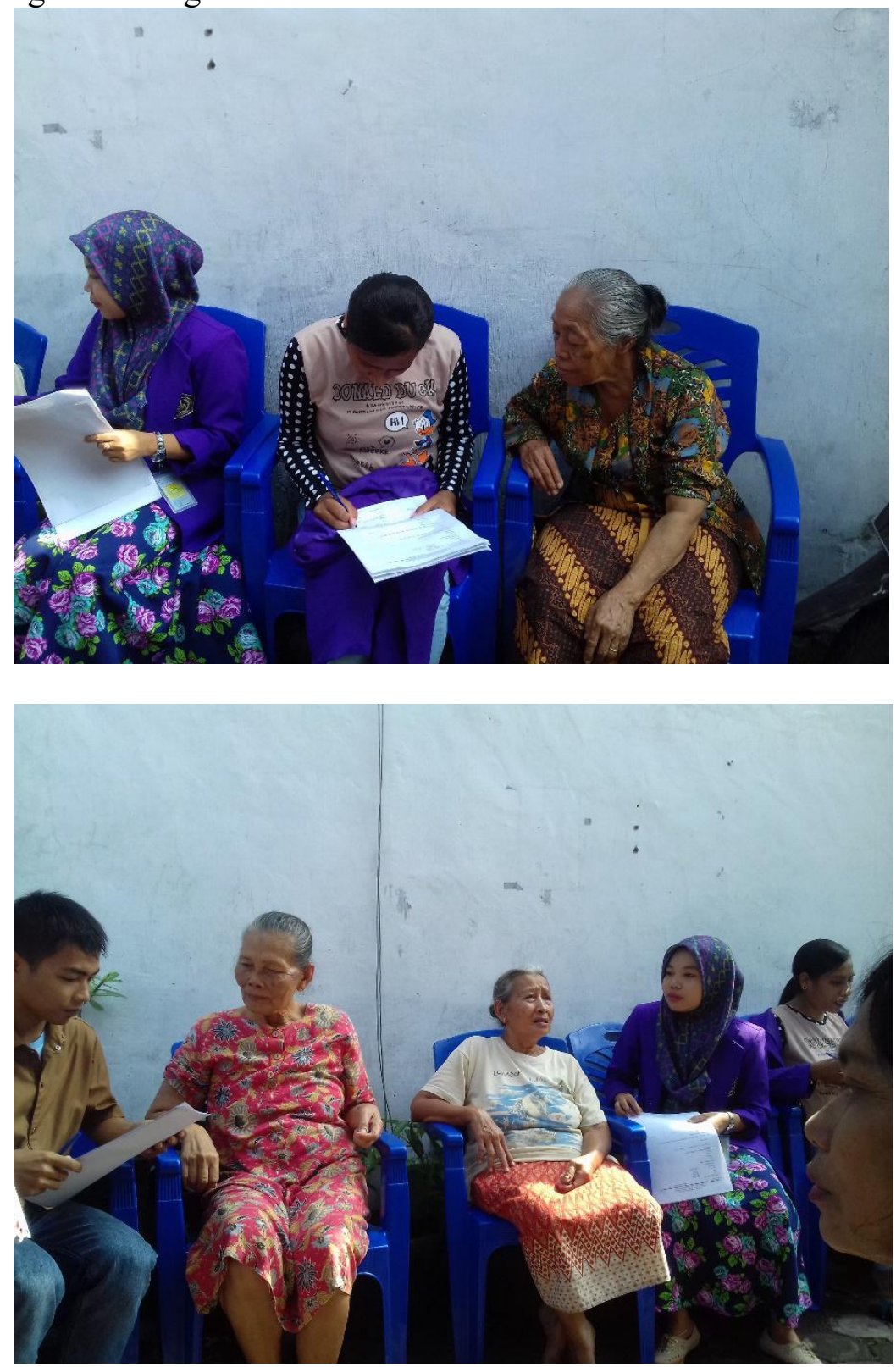


\section{Journal of Community Engagement in Health}

http://jceh.org

ISSN: 2620-3758 (print); 2620-3766 (online)

https://doi.org/10.30994/jceh.v3i1.25

Vol.3 No.1. March 2020. Page.11-20

a. Kegiatan pendampingan Lansia
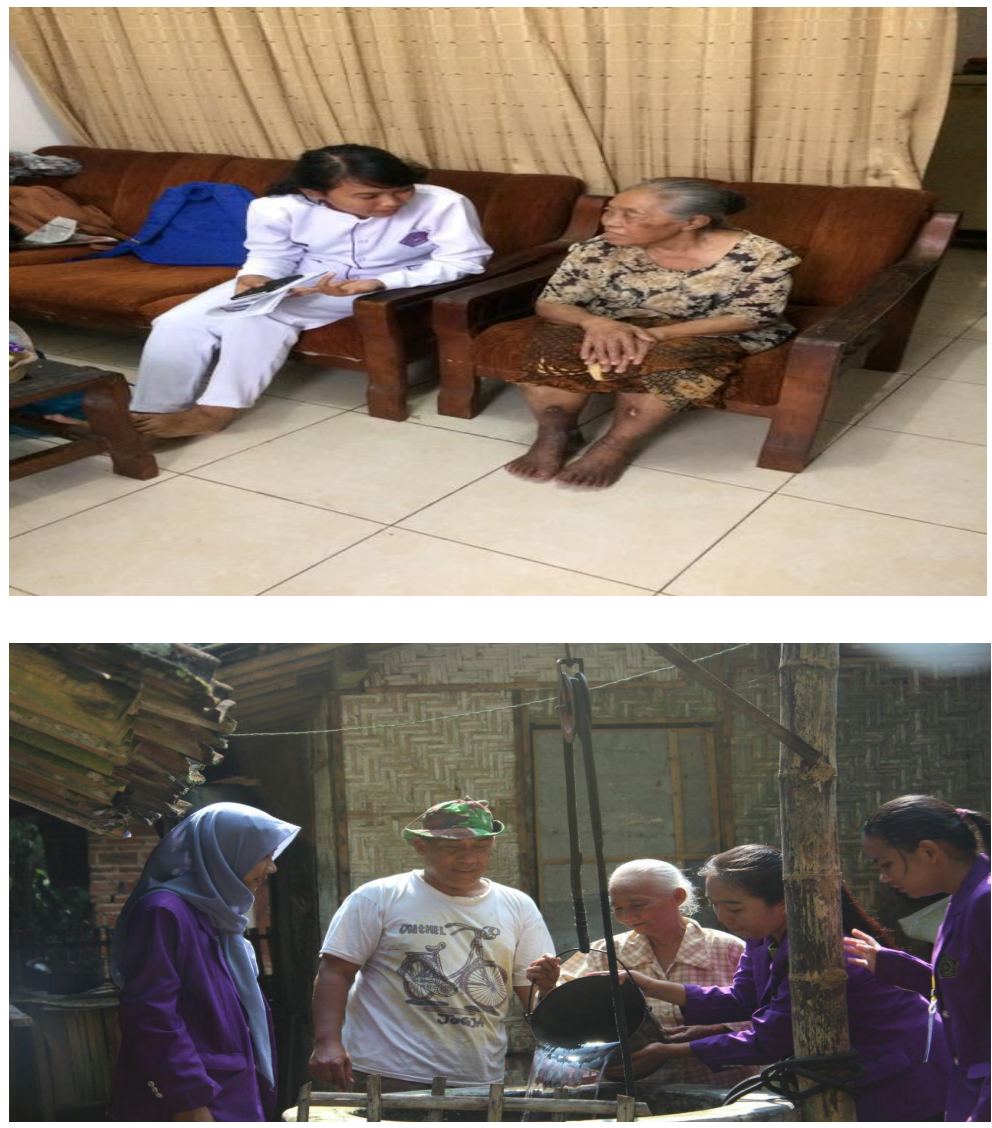

b.Kegiatan senan Otak

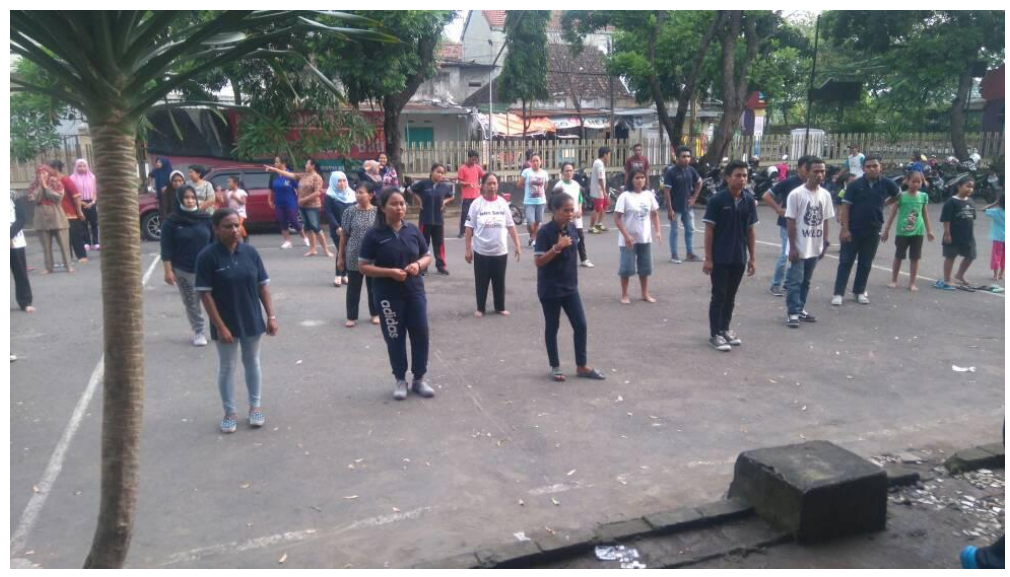




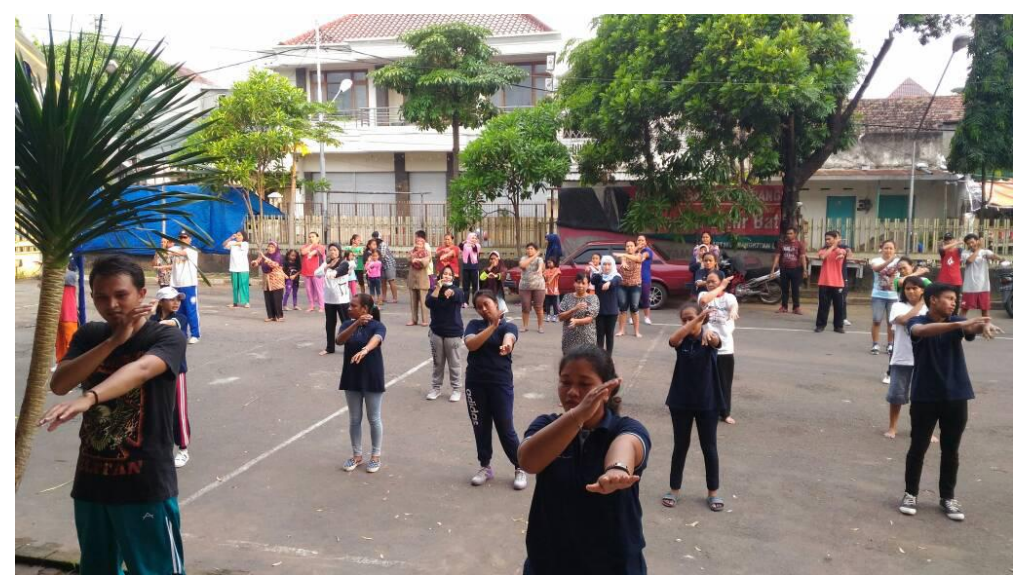

\section{HASIL DAN PEMBAHASAN}

Data pretest hasil penelitian yang telah dilaksanakan di posyandu lansia RW II di kelurahan Pocanan Kota Kediri didapatkan nilai skor uji MMSE 11 lansia tidak mengalami gangguan kognitif, 8 lansia mengalami gangguan kognitif sedang dan 5 lansia mengalami gangguan kognitif berat. Seiring penuaan selain terjadi penurunan fungsi fisik, umumnya terjadi penurunan daya ingat dan kecerdasan. Akibatnya, proses berpikir menjadi lamban, sulit konsentrasi, dan kemampuan daya ingat menurun (Mardiati dan Ratna., 2003). Pemeriksaan fungsi kognitif awal bisa menggunakan Mini Mental State Examinition (MMSE) dengan skor / angka maksimal 30. Jika mempunyai skor dibawah 24, maka pasien mulai mengalami kemunduran daya ingat (Wahjudi, 2008). Berat otak pada lansia berkurang berkaitan dengan berkurangnya kandungan protein dan lemak pada otak sehingga otak menjadi lebih ringan. Akson, dendrite, dan badan sel saraf banyak yang mengalami kematian, sedangkan yang hidup mengalami perubahan. Dendrit yang berfungsi untuk komunikasi antara sel saraf mengalami perubahan menjadi lebih tipis dan kehilangan kontak antar sel saraf. Daya hantar saraf mengalami penurunan $10 \%$ sehingga mengalami penurunan daya ingat ( Mas'ud, 2003). Hal ini menunjukkan responden sudah mulai mengalami penurunan daya ingat karena semua responden sudah memasuki tahap lansia

Dari hasil karakteristik lansia berdasarkan usia, lansia dalam kategori Midlle age (45$\left.59^{\mathrm{Th}}\right)$ berjumlah 4 orang, lansia dengan katagori Elderly $\left(60-74^{\mathrm{Th}}\right)$ berjumlah 8 orang dan lansia dengan katagori old $\left(75-90^{\mathrm{Th}}\right)$ berjumlah 11 orang.

Dari hasil tabulasi silang antara karakteristik responden berdasarkan umur dan kategori gangguan kognitif di dapatkan lansia dalam katagori tidak terjadi gangguan kognitif dan usia middle age sejumlah 4 orang dan usia Elderly sejumlah 7. Sedangkan lansia dengan kategori gangguan kognitif sedang usia elderly sejumlah 4 orang dan usia old 1 orang. Sedangkan lansia dalam kategori gangguan kognitif berat dengan usia elderly sejumlah 3 orang dan usia old 5 orang.

Dari hasil data diatas komposisi lansia di RW II kelurahan pocanan Kota Kediri lebih banyak yang berusia old $\left(75-90^{\mathrm{Th}}\right)$, dimana pada usia tersebut lansia mengalami penurunan koordinasi dan kemampuan dalam melakukan aktivitas sehari-hari. Penuaan menyebabkan penurunan persepsi dan respon motorik pada susunan saraf pusat dan penurunan reseptor proprioseptif. Hal ini terjadi karena susunan saraf pusat pada lansia mengalami perubahan morfologis dan biokimia. Tidak ada hubungan yang signifikan Penyakit dan jenis kelamin dengan daya ingat (Mas'ud, 2003). Hal ini sesuai dengan teori bahwa lansia sudah mengalami penurunan fungsi memori. 
Aktivitas yang mengasah otak akan menguatkan koneksi antara sel saraf dalam otak. Hal ini akan membuat otak semakin kebal terhadap kerusakan. Kegiatan membaca buku juga dapat membuat otak tetap aktif. Sedangkan pendampingan pada lansia yang sudah mengalami dimensia dengan cara : Terapi Audio Gelombang otak Audio gelombang otak dapat berbentuk musik atau lagu lagu yang memiliki karakter menenangkan dan meningkatakan kecerdasan, Meningkatkan konsentrasi dan lebih kreatif dalam berfikir serta mengaktifkan listrik dalam darah menuju jaringan otak. Terapi demensia tersebut Jika dilakukan secara konsisten dapat bermanfaat karena dapat mempertajam intuisi dan daya ingat semakin membaik. Mendengar musik atau lagu sambil mengingat setiap kalimat pada lagu yang telah didengar lalu ditulis diatas kertas, Mendengarkan musik dengan audio gelombang pada frekwensi tertentu mampu menstimulasi otak menjadi lebih aktif dan fokus.

Gerakan senam otak sederhana bermanfaat dalam membantu perkembangan otak secara keseluruhan. selain itu, koordinasi mata, telinga, tangan, dan seluruh anggota tubuh pun dapat diasah melalui senam otak (Soetedjo dan Pramoe. 2003). Dennison (2006) dalam penelitiannya bahwa gerakan - gerakan dalam senam otak dapat mengembangkan otak agar kemampuan daya ingat meningkat. Hal ini di dukung oleh pernyataan bahwa anggota badan yang bergerak dengan gerakan tertentu menyebabkan optimalisasi aliran darah ke otak, merangsang bioelektrik dan terjadi aktivasi sel - sel otak sehingga meningkatkan fungsi otak khususnya pusat memori.

Menurut Kusumoputro dan Djokosetio (2008), kemampuan mengingat merupakan fungsi otak yang kompleks. Proses perolehannya membutuhkan kerjasama yang rapi antara belahan otak kanan dan otak kiri, terutama melalui jembatan korpus kolosum yang berada ditengah-tengahnya. Kalau konsep mengingat langsung merangsang belahan otak kiri. Mengingat adalah pengetahuan yang menggunakan belahan otak kanan mencakup masalah pemahaman visual. Kecerdasan (otak kiri) adalah kemampuan untuk menampung pengetahuan yang diajarkan dan kecerdikan (otak kanan) adalah kemampuan untuk menerapkan kemampuan yang telah diperoleh ke dalam praktik kehidupan seharihari. Ini berarti bahwa untuk memperoleh kemampuan berpikir yang cerdas dan cerdik telah menggunakan keseluruhan bagian otak (Whole Brain). Kemampuan mengingat dapat ditingkatkan dengan senam otak seperti diungkapkan Dr. Dennison dalam Cohen (2007) yang menyatakan bahwa gerakan silang efektif untuk meningkatkan kemampuan otak. Hal itu terjadi karena gerakan silang merangsang bagian otak yang menerima informasi dan juga bagian yang mengungkapkannya.

Ageing Proces dan faktor genetik sangat mempengaruhi daya ingat. Ageing Proces dan faktor genetik bersifat final yang berarti tidak dapat kita ubah. Jika dilihat dari responden, seluruhnya lansia menyebabkan menurunnya fungsi kognitif. Selain faktor faktor di atas, faktor kemauan dan motivasi dari responden sangat mempengaruhi keseriusan dalam melakukan senam otak. Kemauan dan motivasi sangat mempengaruhi corak perbuatan yang akan diperlihatkan. Kemauan dan motivasi ini erat pula hubungannya dengan perhatian yang dimiliki, karena perhatian mengarahkan timbulnya kehendak pada seseorang (Kusumoputro dan Sidiarto. 2003.). Ketika melakukan gerakan senam otak, tidak jarang perhatian responden pada orang lain yang menyaksikan mereka melakukan senam otak sehingga membuat responden tidak serius dalam melakukan gerakan senam otak. Hal ini diluar kendali peneliti karena tempat yang disediakan oleh pihak puskesmas adalah kelurahan dimana biasanya banyak pegawai yang berlalu lalang di tempat tersebut. 
Gerakan - gerakan senam otak yang berhubungan dengan daya ingat adalah Gerakan silang (Cross Crawl), gerakan ini mengaktifkan otak untuk menyeberangi garis tengah penglihatan, kinestetik, perabaan dan sentuhan, gerakan mata dari kiri ke kanan dan meningkatkan kebersamaan penglihatan kedua mata (binokular) Gerakan gajah (The Elephant), gerakan ini mengaktifkan otak untuk menyeberangi garis tengah, meningkatkan daya ingat jangka pendek dan jangka panjang, mengintegrasikan penglihatan, pendengaran, dan gerakan seluruh tubuh, serta meningkatkan kedalaman persepsi dan kemampuan kerjasama mata.

Gerakan putaran leher, gerakan ini mengaktifkan otak untuk penglihatan binokuler, kemampuan membaca dan menulis pada bidang tengah, pemusatan, dan sistem saraf pusat lebih relaks. Pada saat kelelahan, gerakan ini akan menyegarkan otak kembali. Gerakan burung hantu, gerakan ini mengaktifkan otak untuk penglihatan binokuler, kemampuan membaca dan menulis pada bidang tengah, pemusatan, dan merelaksasi sistem saraf pusat. Gerakan lambain tangan, gerakan ini mengaktifkan otak untuk mengendurkan dan merelaksasi otot-otot punggung dan pinggang dari ketegangan serta memompa energi baru. Gerakan pernapasan perut, gerakan ini mengaktifkan otak untuk pemusatan emosional, meningkatkan perhatian, gerakan tulang - tulang kepala.

Setelah di lakukan pendampingan selama 2 minggu pada lansia baik yang sudah mengalami dimensia atau yang belum mengalami dimensia, masyarakat di RW II kelurahan Pocanan Kota Kediri khususnya keluarga lansia menyampaikan bahwa kegiatan yang telah di lakukan dapat menurunkan dimensia pada lansia meskipun belum di ukur lagi menggunakan skor MMSE. Dari evaluasi hasil pemeriksaan dengan MMSE didapatkan data 11 lansia (45,8\%) tidak ada gangguan kognitif, 8 lansia (33,4\%) mengalami gangguan kognitif sedang, 5 lansia ( 20,8\%) mengalami gangguan kognitif berat Kegiatan dalam meningkatkan kognitif lansia harus terus di lakukan dengan di bantu oleh keluarga agar lansia tidak mengalami penurunan kognitifnya sehingga domensia dapat di cegah. Kegiatan senam otak di lakukan oleh lansia melalui posyandu lansia, sehingga setelah selesai kegiatan pengabdian masyarakat yang di lakukan oleh mahasiswa dan dosen STIKes Surya Mitra Husada ini dapat di lanjutkan dan bermanfaat bagi masyarakat khususnya lansia.

\section{SIMPULAN DAN SARAN}

a. Simpulan

Dari hasil pengabdian kepada masyarakat dengan kegiatan pendampingan lansia dengan dimensia di kelurahan pocanan RW II kota Kediri dapat disimpulkan bahwa kegiatan pendampingan lansia dalam upaya mencegah dan menurunkan dimensia pada lansia sangat di perlukan dan dapat membantu lansia dan keluarga dalam pencegahan dan penanganan dimensia pada lansia. Kegiatan yang bisa dilakukan untuk mencegah dan menurunkan dimensia diantaranya mendengarkan musik, berhitung, membaca buku dan senam otak lansia.

b. Saran

Diharapkan setelah kegiatan pengabdian masyarakat yang di lakukan oleh dosen dan mahasiswa IIK STRADA Indonesia berakhir, keluarga lansia dan masyarakat khususnya kader posyandu lansia dapat melanjutkan kegiatan pendampingan lansia dalam rangka mencegah dan mengurangi dimensia pada lansia. 


\section{UCAPAN TERIMAKASIH}

Ucapan terimakasih kami sampaikan kepada segenap pihak yang membantu pelaksanaan kegiatan pengabdian kepada masyarakat ini antara lain kepada Rektor IIK STRADA Indonesia, Kepala kelurahan Pocanan Kota Kediri beserta jajarannya dan pada masyarakat kelurahan Pocanan kota Kediri.

\section{DAFTAR PUSTAKA}

Cohen, David. 2007. Olahraga Otak Melesatkan Otak Kiri Otak Kanan. Bandung: Penerbit JABAL.

Dennison, Paul E. dan Dennison, Gail E. 2005. Senam Otak Buku Panduan Lengkap. Jakarta: PT Grasindo

Dennison, Paul E, 2006 . Buku Panduan Lengkap Brain Gym ( Senam Otak). Jakarta : PT. Gramedia.

Kusumoputro, Sidiarto. 2003. Kiat Panjang Umur Dengan Gerak dan Latih Otak. Jakarta: Penerbit Universitas Indonesia (UI-Press).

Kusumoputro, Sidiarto dan Djokosetio, Lily. 2008. Belajar dan Pola Pikir Berbasis Mekanisme Otak (Whole-Brain Thinking). Jakarta: Penerbit Universitas Indonesia (UI-Press).

Mardiati, Ratna. 2003. Buku Kuliah Susunan Saraf Otak Manusia. Jakarta: Sagung Seto

Mas'ud, Ibnu. 2003. FISIOLOGI (Persepsi Kerja Otak Manusia). Malang: Lembaga Penerbitan Universitas Brawijaya Malang

Soetedjo, Pramoe. 2003. Bersenam dan Pengetahuan Olah Raga. Malang: MAN I Malang.

Wahjudi, Nugroho. 2008. Keperawatan Gerontik \&Geriatrik. Jakarta: EGC. 